\title{
Influence of the Tungurahua eruption on the ice core records of Chimborazo, Ecuador
}

\author{
P. Ginot ${ }^{1,2}$, U. Schotterer ${ }^{3}$, W. Stichler ${ }^{4}$, M. A. Godoi ${ }^{5,6}$, B. Francou ${ }^{7}$, and M. Schwikowski ${ }^{5}$ \\ ${ }^{1}$ Institut de Recherche pour le Développement (IRD), UMS222 OSUG, France \\ ${ }^{2}$ Laboratoire de Glaciologie et Géophysique de l'Environnement (LGGE), UMR5183, St Martin d'Hères, France \\ ${ }^{3}$ Division of Climate and Environmental Physics, University of Berne, Switzerland \\ ${ }^{4}$ HZM-Institute for Groundwater Ecology, Neuherberg, Germany \\ ${ }^{5}$ Paul Scherrer Institute (PSI), Villigen, Switzerland \\ ${ }^{6}$ Dirección de Programas Antárticos, Instituto de la Patagonia, Universidad de Magallanes, Punta Arenas, Chile \\ ${ }^{7}$ Institut de Recherche pour le Développement (IRD), UMR012 LTHE, Ecuador
}

Received: 10 August 2010 - Published in The Cryosphere Discuss.: 20 August 2010

Revised: 26 November 2010 - Accepted: 26 November 2010 - Published: 8 December 2010

\begin{abstract}
The comparison of two shallow ice cores recovered in 1999 and 2000 from the same place on the Chimborazo summit glacier revealed the influence of the coincident Tungurahua volcanic eruption on their stable isotope and chemical records. The surface snow melting and water percolation induced from the ash deposition caused a preferential elution and re-localization of certain ionic species, while the stable isotope records were not affected. Additionally, the comparison of the ionic amount and some selected ion ratios preserved along the ice core column reports under which processes the chemical species are introduced in the snow pack, as snow flake condensation nuclei, by atmospheric scavenging or by dry deposition. This preliminary study is essential for the interpretation of the deep Chimborazo ice core, or for other sites where surrounding volcanic activity influences the glaciochemical records.
\end{abstract}

\section{Introduction}

Mid- and low-latitude glacier ice cores have great potential as environmental and climatic archives. This has been demonstrated by several previous studies in the Andes e.g. (Thompson et al., 1979, 1995, 1998; Ginot et al., 2002; Schotterer et al., 2003; Henderson et al., 1999; Knüsel et al., 2003), in the Alps e.g. (Preunkert et al., 2000; Döscher et al., 1995; Eich-

Correspondence to: P. Ginot

(patrick.ginot@ird.fr) ler et al., 2000; Schwikowski et al., 1999; Schotterer et al., 1997), in Africa (Thompson et al., 2002) and in Central Asia e.g. (Olivier et al., 2003; Thompson et al., 1997, 2000; Kang et al., 2002; Kreutz and Sholkovitz, 2000). However, as a proxy record, the interpretation of the information recorded in an ice core is far from trivial. Several processes determine how the climatic and environmental information is written in the ice: origin and recycling of moisture, air masses circulation and mixing, in-cloud scavenging of aerosol particles as condensation nuclei and below-cloud scavenging of particles and gases by ice crystals and snow flakes, dry deposition, post-depositional processes etc. As described by (Ginot et al., 2001; Stichler et al., 2001; Schotterer et al., 2004), post-depositional processes in the Andes include surface snow sublimation, surface melting and wind drift. In this study, we investigated the effect of percolation of surface melt water on Chimborazo summit glacier caused by a volcanic eruption in the vicinity, and the implications on the recovered ice core records.

Chimborazo $\left(6268 \mathrm{~m}, 1^{\circ} 30^{\prime} \mathrm{S}, 78^{\circ} 36^{\prime} \mathrm{W}\right)$ is located on the eastern border of the Occidental Cordillera in Ecuador (Fig. 1). This double-peak inactive volcano (Cumbre Ventimilla and Cumbre Whymper) receives precipitation originating from both West (Pacific Ocean) and East (Atlantic Ocean and Amazon basin) sides, depending on the position of the Inter Tropical Convergence Zone (ITCZ). Thus, the annual precipitation pattern on Chimborazo reflects a varying influence from oceanic and continental air masses with two rainy seasons (February-May and October-November) and two dry seasons, the first one "Verano" (June-September)

Published by Copernicus Publications on behalf of the European Geosciences Union. 

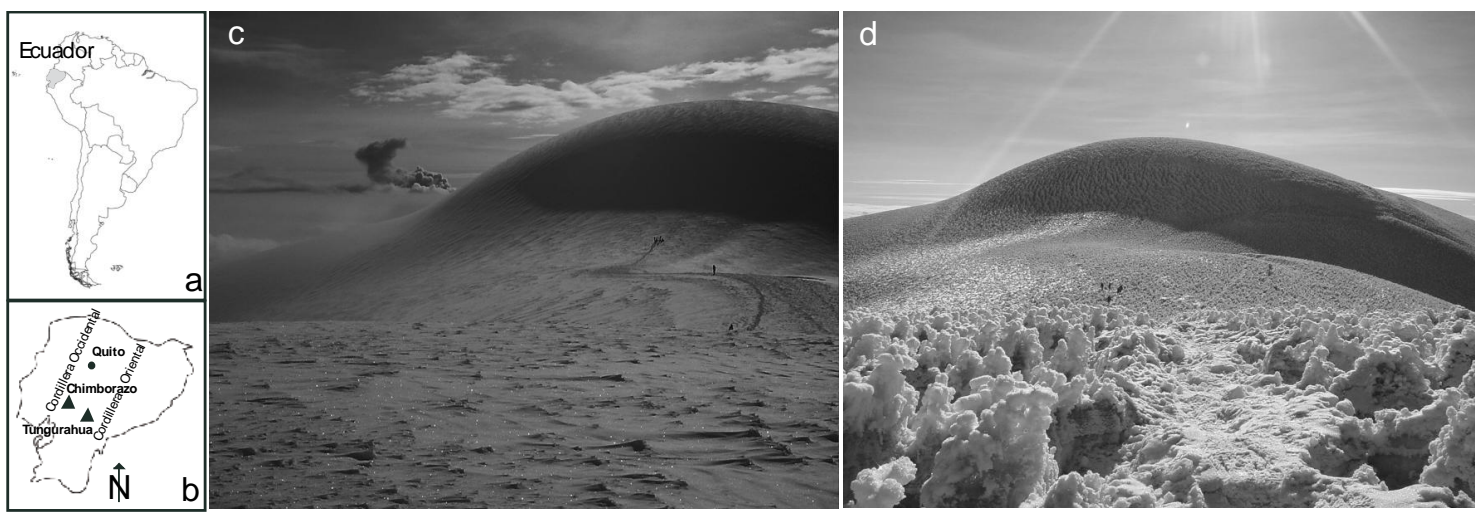

Fig. 1. Map of South America (a) and Ecuador (b), showing the location of Chimborazo and Tungurahua summits. Views of Chimborazo Cumbre Whymper $(6268 \mathrm{~m})$ and middle plateau from Cumbre Ventimilla $(6230 \mathrm{~m})$ in 1999 (c) and 2000 (d). A smooth snow surface was encountered in December 1999, whereas the Tungurahua eruption (ash plume visible in the background) transformed the glacier surface, which was completely covered with ash, penitents and hoarfrost in December 2000.

much more pronounced than the second one "Veranillo" around December (Vuille et al., 2000).

As part of a reconnaissance in December 1999, a $16.5 \mathrm{~m}$ shallow ice core was drilled on Cumbre Ventimilla in order to investigate the suitability of the site to preserve (1) the climatic and environmental records, and (2) the seasonality of the signal. Since the shallow core revealed wellpreserved signals, a deep drilling campaign was conducted one year later, in December 2000, and four ice cores were recovered. Three cores were drilled on Cumbre Ventimilla (54 $\mathrm{m}$ to bedrock, $40 \mathrm{~m}$ and $17 \mathrm{~m}$ ), and one on the plateau located between both summits (Cumbre Ventimilla and Cumbre Whymper), which reached water saturated firn at $23 \mathrm{~m}$ depth. All cores were transported and preserved frozen until analyzed. In the same period, starting in October 1999 and continuing in 2000, the eruption of the adjacent volcano Tungurahua $\left(5023 \mathrm{~m}, 1^{\circ} 47^{\prime} \mathrm{S}, 78^{\circ} 44^{\prime} \mathrm{W}\right)$ covered the Chimborazo glacier surface with a few mm thick ash layer. Whereas a smooth snow surface with only some hoarfrost structures was encountered in 1999 (Fig. 1a, with Tungurahua ash plume in the background), in 2000 the glacier was completely covered with meter high "ice penitents" enveloped with dark ash layers (Fig. 1b). This change of the surface structure evokes the fusion of the upper layer. Between July and December 1999, the volcanic emission of $\mathrm{SO}_{2}$ increased to $10000 \mathrm{tday}^{-1}$ and ash plumes reached $\sim 10 \mathrm{~km}$ altitude in 2000 (Source: Smithsonian Global Volcanic Program; http://www.volcano.si.edu/).

In order to study the influence of this volcanic eruption on the glaciochemical record, the $16.5 \mathrm{~m}$ core from 1999 (core A) and the $17 \mathrm{~m}$ one from 2000 (core B) were analyzed and compared. Core A and B were sub-sampled in 268 and 261 continuous samples, respectively, and analyzed for major ions by ion chromatography $\left(\mathrm{Na}^{+}, \mathrm{K}^{+}, \mathrm{Mg}^{2+}, \mathrm{Ca}^{2+}\right.$, $\mathrm{NH}_{4}^{+}, \mathrm{SO}_{4}^{2-}, \mathrm{NO}_{3}^{-}, \mathrm{Cl}^{-}, \mathrm{F}^{-}$, and $\mathrm{HCO}_{2}^{-}$), stables isotopes $\left(\delta^{18} \mathrm{O}, \delta^{2} \mathrm{H}\right)$, Electro-conductivity (core B only) using procedures described in (Ginot et al., 2001) and (Knüsel et al., 2003). $\mathrm{H}^{+}$was calculated from the ionic balance.

The comparison of the two cores leads to the determination and discussion of each specific ion behavior under this volcanic perturbation, the control of the ionic budget conserved in the ice core column, and the determination of some adequate ionic ratio as indicator to some processes.

\section{Ice cores records}

\subsection{Ice core A - 1999}

The general feature of the glaciochemical record is a strong seasonality of major ion concentrations and stable isotope ratios (Fig. 2). This is explained by the complex annual precipitation pattern on Chimborazo often resulting in a bimodal peak, similar to that observed in a previous study of stable isotope ratios in monthly composites of Ecuadorian precipitation. Because of the proximity to the equator the air temperatures measured in all meteorological stations are relatively constant throughout the year. Temperature therefore does not play a significant role in the seasonal pattern of stable isotopes in precipitation; it is the amount of precipitation and the link to the passage of the ITCZ. In the Andean domain (Quito and Izobamba) the $\delta^{18} \mathrm{O}$ values range between $-7 \%$ and $-9 \%$ during the two dry seasons and between $-10 \%$ and $-16 \%$ during the rainy seasons. As mentioned, "Veranillo" is less pronounced and not always visible in the isotope record (Garcia et al., 1998 and the Global Network for Isotopes in Precipitation GNIP, IAEA, Vienna, http://nds121.iaea.org/wiser/). In the Chimborazo ice cores the $\delta^{18} \mathrm{O}$ values range between $-12 \%$ and $-15 \%$ o during the dry seasons and between $-16 \%$ and $-22 \%$ o during the rainy seasons. In the 12 years time interval ( \pm 1 years) as recorded 


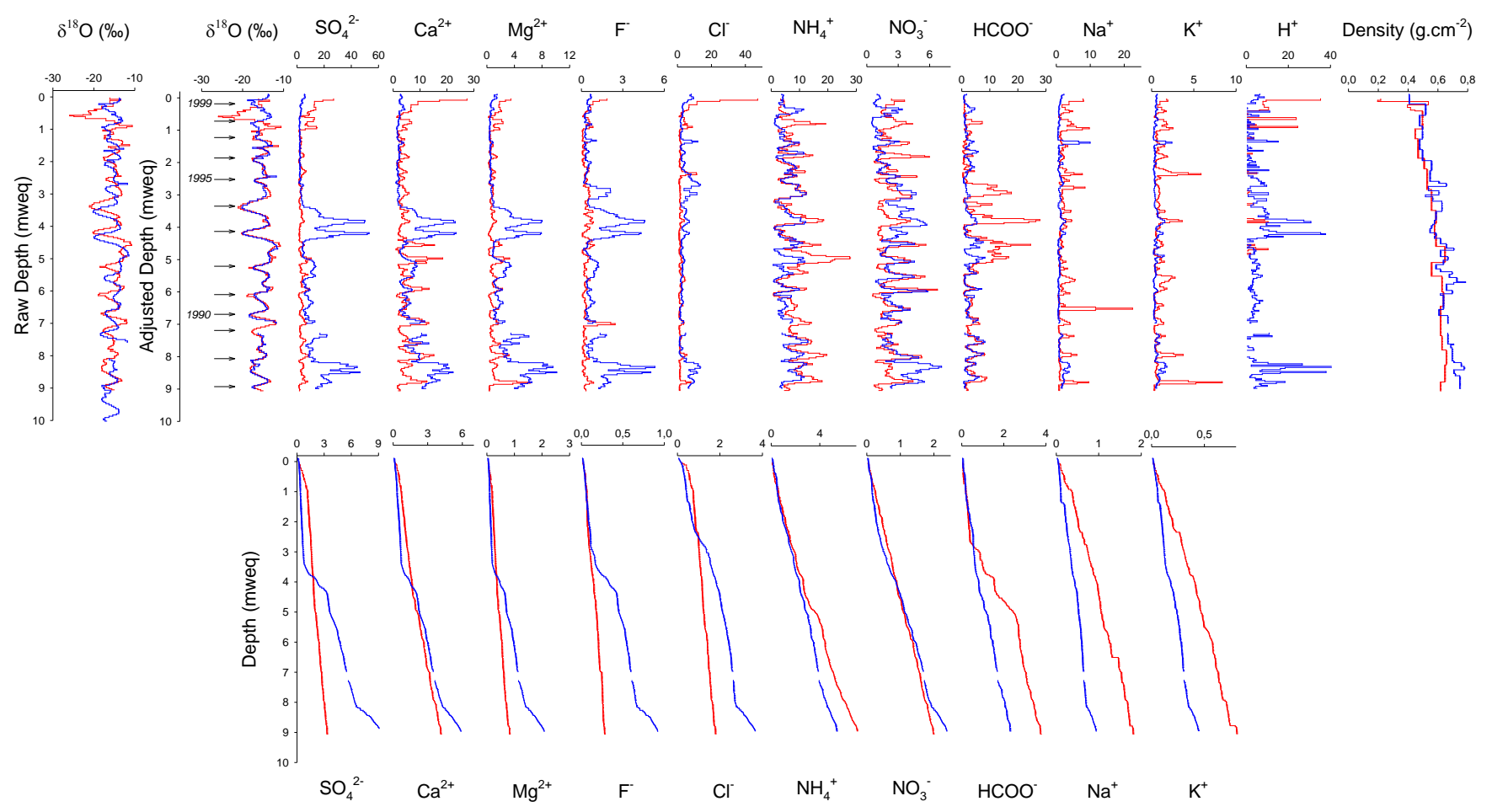

Fig. 2. (a) Comparison of $\delta^{18} \mathrm{O}$, major ion concentration and density profiles recorded in core A (1999, red line) and B (2000, blue line). Ion concentrations are in $\mu \mathrm{EqL}^{-1}$. (b) Cumulated deposition fluxes of the different ions (in $\mathrm{mg} \mathrm{cm}^{-2}$ ). The depth scale of core $\mathrm{B}$ is adjusted to that of core $\mathrm{A}$ by matching of the $\delta^{18} \mathrm{O}$ records. The arrow indicates the limit of some contiguous bimodal shape years.

by the stable isotopes, three to four "Veranillos" can be identified by little negative dips interrupting the general positive $\delta^{18} \mathrm{O}$ trend during the dry season (Fig. 2).

The high concentrations of $\mathrm{SO}_{4}^{2-}, \mathrm{Cl}^{-}, \mathrm{F}^{-}, \mathrm{H}^{+}, \mathrm{Ca}^{2+}$ and $\mathrm{Mg}^{2+}$ in the topmost $20 \mathrm{~cm}$ weq of the records (Fig. 2) are due to input of volcanic material such as mineral acids $\left(\mathrm{H}_{2} \mathrm{SO}_{4}, \mathrm{HCl}, \mathrm{HF}\right)$ and fine volcanic ash $(\mathrm{CaO}, \mathrm{MgO})$, since the Tungurahua eruption started in October 1999. The seasonal variations reported from the stable isotopes allow the identification of the chemical species following the same seasonal pattern. Terrestrial salts coming with primary aerosols $\left(\mathrm{Ca}^{2+}, \mathrm{Mg}^{2+}, \mathrm{SO}_{4}^{2+}, \mathrm{CO}_{3}^{2-}\right)$ are trapped in the snow by atmospheric scavenging or dry deposition (Delmas, 1992; Legrand and Mayewski, 1997) during wet and dry seasons respectively, and follow the hydrological bimodal cycles. $\mathrm{Na}^{+}, \mathrm{Cl}^{-}$and $\mathrm{K}^{+}$, principal sea salt aerosol may show higher concentrations during the first rainy season (February-May) directly influenced by air masses originating in the Pacific. However, this relationship is not clearly marked in the record. $\mathrm{NO}_{3}^{-}, \mathrm{NH}_{4}^{+}$and $\mathrm{HCOO}^{-}$emitted from the biogenic activities and biomass burning reports high concentrations during both annual warm seasons according to the increase of local agriculture productivity and natural or human forest and field burning ("chaqueo") (Legrand et al., 1992; Legrand and De Angelis, 1996).

\subsection{Ice core B - 2000}

In order to compare the two ice core records, they had to be adjusted in depth scale to account for the different sampling times. As observed in Fig. 2, some shifts in the raw depth scale are present in the comparison of both $\delta^{18} \mathrm{O}$ records. For this purpose the $\delta^{18} \mathrm{O}$ records were used, assuming that they were least affected by surface melting and melt water percolation, resulting from lowering of the surface albedo due to the volcanic ash layer. This assumption is valid as long as the melt water percolates through the firn layers without refreezing until the impermeable firn-ice transition is reached. The $\delta^{18} \mathrm{O}$ profile from core $\mathrm{A}$ was used as reference and the core B profile was stretched-shrinked in depth until best fit resulting in a $10 \%$ length reduction correction. The resulting records are shown in Fig. 2. The $150 \mathrm{~mm}$ weq shift of the core B record surfaces reflects the net-accumulation between December 1999 and December 2000, which is significantly lower than mean annual net-accumulation of $760 \mathrm{~mm}$ weq deduced from $12 \pm 1$ years annual counting over core $A$. This deficit is explained by surface ablation/melting related to the volcanic event. Moreover, the upper part of the $\delta^{18} \mathrm{O}$ record of core B, between surface and $1 \mathrm{~m}$ weq depth, is drastically perturbed. This indicates that in addition to melting also partial refreezing of the melt water took place in this layer. Deeper, between 1 and $9 \mathrm{~m}$ weq, the two records agree well. 
Thus, no significant melt water refreezing occurred in this section. The new depth scale for core B was used for the comparison of the cores. The measured borehole temperature until $17 \mathrm{~m}$ depth ranged between -4.6 and $-4.7^{\circ} \mathrm{C}$.

All core $\mathrm{B}$ chemical profiles are compared with those of core A in Fig. 2. Of all species, $\mathrm{NH}_{4}^{+}$and $\mathrm{NO}_{3}^{-}$show the best agreement between the two cores. Apparent exceptions are the upper $1 \mathrm{~m}$ weq and the regions around $4.9 \mathrm{~m}$ weq depth $\left(\mathrm{NH}_{4}^{+}\right)$and between $3-4.5$ and $8.2-8.8 \mathrm{~m}$ weq depth $\left(\mathrm{NO}_{3}^{-}\right)$. In contrast, the $\mathrm{Ca}^{2+}, \mathrm{Mg}^{2+}, \mathrm{SO}_{4}^{2-}$ and $\mathrm{F}^{-}$records in core $\mathrm{A}$ and $\mathrm{B}$ show major differences. Between surface and $3.4 \mathrm{~m}$ weq depth, concentrations in core B profiles are low, in the order of the background level of core A, and the seasonal variation is no longer visible. At $3.3-4.4 \mathrm{~m}$ weq and 8.0-9.0 $\mathrm{m}$ weq depth, the highest concentration peaks appeared, also seen in $\mathrm{H}^{+}$. Between 4.4 and $8.0 \mathrm{~m}$ weq depth, the profile structures show some similarities, but with slightly higher concentrations in core $\mathrm{B} . \mathrm{K}^{+}, \mathrm{Na}^{+}, \mathrm{Cl}^{-}$profiles from core $\mathrm{B}$ are smoothed but conserved some similarities. The $\mathrm{HCOO}^{-}$record $\mathrm{B}$ is disturbed down to $5 \mathrm{~m}$ weq depth, while it is well conserved in the deeper part.

\section{Discussions}

Volcanic emissions and deposition on the glacier surface started with the eruption of Tungurahua in July 1999 and peaked in September-October with $\sim 9000-10000$ tons/day of $\mathrm{SO}_{2}$. The $\mathrm{H}_{2} \mathrm{SO}_{4}, \mathrm{HCl}$ and $\mathrm{HF}$ depositions are well visible in the topmost $20 \mathrm{~cm}$ of core $\mathrm{A}$, which was recovered in December 1999. The main explosive phases of the volcano began in January 2000 with ash plumes rising to $\sim 10 \mathrm{~km}$ altitude and tephra frequently blown to the West, the direction to Chimborazo glacier. This second phase decreased the surface snow albedo and followed by the dry season "verano" conditions were favorable to surface snow melting and sublimation. The $150 \mathrm{~mm}$ weq net-accumulation between December 1999 and 2000 compared with $760 \mathrm{~mm}$ weq mean annual netaccumulation suggests about $600 \mathrm{~mm}$ weq of ablation (melting and sublimation). Because of a relatively high firn temperature $\left(\sim-4.6^{\circ} \mathrm{C}\right)$, the melt water percolated through the entire firn layer without major refreezing, presumably down to the firn/ice transition at about $23 \mathrm{~m}$ depth (H. Bonnaveira, personal communication, 2001).

The eruption of volcano Tungurahua had multiple effects on the Chimborazo glacier. The first effect, visible on the surface, was the deposition of dark volcanic ash between October 1999 and December 2000 that lowered surface snow albedo. The lower albedo induced surface snow melting and sublimation, resulting in the formation of "ice penitents" visible in Fig. 1. The second effect was the input of the acids $\mathrm{H}_{2} \mathrm{SO}_{4}, \mathrm{HCl}$ and $\mathrm{HF}$ as well as volcanic ash containing $\mathrm{CaO}$ and $\mathrm{MgO}$. The third effect was the percolation of melt water, containing high concentrations of soluble ions of volcanic origin, through the entire firn layer. The melt water pulse caused an input of certain ions into the firn layer, but was also responsible for preferential elution and relocation of ions originally present in the firn.

\subsection{Preferential elution of ions}

As demonstrated by previous studies (Davies et al., 1982; Hou and Qin, 2002; Pohjola et al., 2002; Grumet et al., 1998; Brimblecombe et al., 1985; Tsiouris et al., 1985; Eichler et al., 2001), strong acids, and $\mathrm{H}_{2} \mathrm{SO}_{4}$ in particular, are preferentially eluted by melt water because the corresponding ions are expected to be enriched at firn grain boundaries. In our case, the highest $\mathrm{SO}_{4}^{2-}$ concentration peak observed in core A between surface and $1 \mathrm{~m}$ weq depth related to volcanic deposits, and the usual seasonal concentration variability persisting down to $3.3 \mathrm{~m}$ weq depth, was completely removed in core $\mathrm{B}$; the mean concentration decreased from 3.88 to $1.88 \mu \mathrm{Eq} \mathrm{L}^{-1}$ for this section (Table 1). This section of the snowpack is followed by a segment where $\mathrm{SO}_{4}^{2-}$ appeared in two peaks between 3.3 and $4.4 \mathrm{~m}$ weq depth, showing the highest concentrations in entire core $\mathrm{B}$ with a mean of $22.34 \mu \mathrm{EqL} \mathrm{L}^{-1}$. It is not clear which process dominated this relocation in an area with originally low concentrations in core A. Hou and Qin (2002) suggested that percolating highly concentrated melt water refroze on top of impermeable ice layers formed in the previous summer, which act as physical obstacle against melt water percolation. However, such ice layers were not present in core B and, in addition, there is no indication of a major refreezing in the $\delta^{18} \mathrm{O}$ record. In the considered section, density increases from 0.44 to $0.55 \mathrm{~g} \mathrm{~cm}^{-3}$ and reaches a major stratigraphic change with the end of the first stage of densification (Herron and Langway, 1980), where the dominant mechanism is considered to be grain settling and packing. Probably the re-deposition of $\mathrm{SO}_{4}^{2-}$ in this region is related to the stratigraphic transition. Between 4.4 and $8.1 \mathrm{~m}$ weq depth, some structures from core $\mathrm{A}$ are conserved in core $\mathrm{B}$, but with additional peaks and a higher background (Table 1). In the deepest part of the record between 8.1 and $9 \mathrm{~m}$ weq a second relocation zone was observed, where core B mean $\mathrm{SO}_{4}^{2-}$ reached $24.51 \mu \mathrm{EqL}^{-1}$ in comparison with the $3.33 \mu \mathrm{Eq} \mathrm{L}^{-1}$ in core A.

$\mathrm{H}^{+}, \mathrm{F}^{-}, \mathrm{Ca}^{2+}$, and $\mathrm{Mg}^{2+}$ show a similar behavior as $\mathrm{SO}_{4}^{2-}$. The tendency of $\mathrm{Ca}^{2+}$ and $\mathrm{Mg}^{2+}$ to be eluted and relocated easily was observed in previous studies (Davies et al., 1982; Tsiouris et al., 1985; Eichler et al., 2001). This observation was explained by exclusion of these ions from the ice lattice into boundary regions during grain growth, which makes them accessible for percolating melt water (Eichler et al., 2001). This exclusion process might even be more effective on Chimborazo, since $\mathrm{Ca}^{2+}$ and $\mathrm{Mg}^{2+}$ originating from local terrestrial salts, are preferentially incorporated in the snow pack during the dry seasons by dry deposition. Leaching of $\mathrm{Ca}^{2+}$ and $\mathrm{Mg}^{2+}$ in the volcanic ash layer is facilitated by the acidic conditions, resulting in a similar elution and relocation behavior as observed for $\mathrm{SO}_{4}^{2-}$ (see Table 1). $\mathrm{F}^{-}$ 
Table 1. Mean concentrations $\left(\mu \mathrm{EqL} \mathrm{L}^{-1}\right.$ ) for core A and B sections (depth in m weq). Bold values indicate major redeposition sections.

\begin{tabular}{l|rr|rr|rr|r|rr}
\hline & \multicolumn{2}{|c|}{$0-3.3$} & \multicolumn{2}{c|}{$\mathbf{3 . 3 - 4 . 4}$} & \multicolumn{2}{c}{$4.4-8.1$} & \multicolumn{2}{|c|}{$\mathbf{8 . 1 - 9 . 1}$} \\
\hline & core A & core B & core A & core B & core A & core B & core A & core B \\
\hline $\mathrm{NH}_{4}^{+}$ & 6.17 & 5.07 & 6.82 & 5.44 & 8.96 & 5.45 & 10.66 & 7.43 \\
$\mathrm{Ca}^{2+}$ & 3.53 & 1.75 & 3.19 & $\mathbf{1 2 . 0 0}$ & 5.22 & 5.72 & 5.48 & $\mathbf{1 5 . 0 8}$ \\
$\mathrm{Mg}^{2+}$ & 0.74 & 0.42 & 0.60 & $\mathbf{4 . 1 0}$ & 0.87 & 1.93 & 1.29 & $\mathbf{6 . 3 4}$ \\
$\mathrm{K}^{+}$ & 0.96 & 0.34 & 0.93 & 0.70 & 0.72 & 0.36 & 1.14 & 0.88 \\
$\mathrm{Na}^{+}$ & 2.28 & 0.92 & 1.84 & 1.24 & 1.82 & 0.56 & 1.61 & 2.16 \\
$\mathrm{~F}^{-}$ & 0.38 & 0.42 & 0.56 & $\mathbf{2 . 3 2}$ & 0.40 & 0.63 & 0.39 & $\mathbf{2 . 3 5}$ \\
$\mathrm{Cl}^{-}$ & 2.56 & 3.91 & 1.14 & $\mathbf{3 . 9 5}$ & 1.21 & 2.01 & 1.65 & $\mathbf{8 . 3 5}$ \\
$\mathrm{NO}_{3}^{-}$ & 2.17 & 1.60 & 1.78 & 3.39 & 2.28 & 2.40 & 2.23 & 4.31 \\
$\mathrm{SO}_{4}^{2-}$ & 3.88 & 1.73 & 2.04 & $\mathbf{2 2 . 9 9}$ & 3.09 & $\mathbf{8 . 1 8}$ & 3.33 & $\mathbf{2 5 . 1 2}$ \\
$\mathrm{HCOO}^{-}$ & 2.57 & 1.75 & 6.64 & 2.52 & 4.84 & 3.01 & 3.57 & 2.24 \\
\hline
\end{tabular}

seems to be less affected by relocation; at least in the upper part of core B (1-3 m weq depth) the original structure is preserved. This is consistent with previous studies, suggesting high solubility of $\mathrm{F}^{-}$in ice and accordingly a low susceptibility against elution (Eichler et al., 2001). However the overwhelming effect in the Chimborazo record is the volcanic $\mathrm{F}^{-}$input with the melt water pulse, most probably in form of HF. Interestingly, this additional $\mathrm{F}^{-}$is redeposited in the same core regions as $\mathrm{SO}_{4}^{2-}, \mathrm{Ca}^{2+}$, and $\mathrm{Mg}^{2+}$ (Table 1).

$\mathrm{NH}_{4}^{+}$is the best preserved ion as indicated by the good correspondence between core $\mathrm{A}$ and $\mathrm{B}$, in agreement with previous studies (Eichler et al., 2001; Pohjola et al., 2002). In these studies, this behavior was explained by the easy incorporation of $\mathrm{NH}_{4}^{+}$into the ice crystal lattice. $\mathrm{HCOO}^{-}$is assumed to be incorporated in the snowpack as ammonium formate (correlation coefficient between concentrations of $\mathrm{NH}_{4}^{+}$ and $\mathrm{HCOO}^{-}$in core $\mathrm{A}: r=0.69$ ), and the profile is well preserved between 5.0 and $9.1 \mathrm{~m}$ weq depth with some discrepancies in the upper part.

In contrast to polar regions where $\mathrm{NO}_{3}^{-}$is present as $\mathrm{HNO}_{3}$ and is eluted like $\mathrm{SO}_{4}^{2-}$ (Davies et al., 1982; Pohjola et al., 2002); on Chimborazo, $\mathrm{NO}_{3}^{-}$is most probably introduced as $\mathrm{NH}_{4} \mathrm{NO}_{3}$ and preserved in the ice lattice, as it was observed in an ice core from the Alps (Eichler et al., 2001). However, slight relocation of $\mathrm{NO}_{3}^{-}$is visible and redeposition occurred at the same depth as for the other ions $\mathrm{SO}_{4}^{2-}, \mathrm{F}^{-}, \mathrm{Ca}^{2+}$, and $\mathrm{Mg}^{2+}$.

The $\mathrm{Cl}^{-}$profile in core $\mathrm{B}$ is dominated by the strong volcanic input $\left(>46 \mu \mathrm{EqL}^{-1}\right.$ in the surface layer of core $\mathrm{A}$ ), which was eluted and redistributed all over the core B as indicated by the mean values of the 4 core sections in Table 1 . Redeposition is less pronounced than for the other ions, but occurred in the same regions. $\mathrm{Na}^{+}$and $\mathrm{K}^{+}$records, which were not affected by additional input from volcanic material, showed a strong elution caused by the melt water percolation
(Table 1). This high mobility of $\mathrm{Na}^{+}$and $\mathrm{K}^{+}$was described previously (Eichler et al., 2001).

\subsection{Accumulated deposition fluxes}

In order to compare the input, output, and relocation of different ionic species along the cores, accumulated ion deposition fluxes were calculated. In Fig. $2 b$ accumulated fluxes of each ion (expressed in $\mathrm{mg} \mathrm{cm}^{-2}$ ) are compared for both cores. The first information is the total flux of the selected species present in the cores, which is the respective value at $9 \mathrm{~m}$ weq depth, the bottom of the cores. Three groups of ions can be identified.

The first group consists of $\mathrm{SO}_{4}^{2-}, \mathrm{F}^{-}, \mathrm{Ca}^{2+}, \mathrm{Mg}^{2+}$, and $\mathrm{Cl}^{-}$, and for which the total flux of core $\mathrm{B}$ is much larger than for core A. For example, the total $\mathrm{SO}_{4}^{2-}$ fluxes for core A and $B$ are 3.21 and $9.17 \mathrm{mg} \mathrm{cm}^{-2}$, respectively. This difference is attributed to the additional input due to the volcanic activity. Between December 1999 and 2000, the eruption of Tungurahua continued to deposit these species on the glacier surface and the volcanic activity was particularly high in the year 2000. Since melt water drainage occurred (see below), the total volcanic input cannot be determined. In the flux curves in Fig. 2b, the initial surface input is characterized by the rounded start of the core A curve, and the redeposition layers in core B, by the inflection of the curves at 3.3 and $8.1 \mathrm{~m}$ weq depth.

The second group of species, $\mathrm{Na}^{+}, \mathrm{K}^{+}$and $\mathrm{HCOO}^{-}$, showed higher total fluxes in core A, e.g. the $\mathrm{Na}^{+}$flux decreased from $1.79 \mathrm{mg} \mathrm{cm}^{-2}$ in 1999 to $0.92 \mathrm{mg} \mathrm{cm}^{-2}$ in 2000. This can only be explained by the fact that melt water percolation was not stopped at the deepest part of core B, but instead melt water drainage occurred. As we know from the drilling performed on the pass between the two Chimborazo summits, a large quantity of liquid water was stored above the firn/ice transition at about $23 \mathrm{~m}$ depth. It seems that 
the surface melt water on Chimborazo Cumbre Ventimilla, where cores A and B were recovered, percolated through the entire firn layer until reaching the ice interface, and drained down to the lower pass. This drainage must have affected ions of group one as well, but there it was overcompensated by the volcanic input.

The last group of species consists of $\mathrm{NH}_{4}^{+}$and $\mathrm{NO}_{3}^{-}$. As discussed above, these species are less affected by elution and redeposition processes and accordingly the total accumulated deposition flux curves from core A and B agree reasonably well.

\subsection{Ionic ratios}

The examination of ionic ratios between species exhibiting different behaviors allows a better characterization of these elution and migration processes. The $\mathrm{SO}_{4}^{2-} / \mathrm{NH}_{4}^{+}$ratio (Fig. 3) compares two ions with opposite position in the elution sequence. The ratio is quite constant with a mean of about 0.40 under $1 \mathrm{~m}$ weq depth but with higher values in the first meter under surface. This indicates well the sulfate excess stored in the upper meter corresponding to the recent volcanic input. For core B, the sulfate excess is shifted under $3 \mathrm{~m}$ weq depth into several layers, the highest concentration located between 3.3 and $4.4 \mathrm{~m}$ weq depth. The $\mathrm{SO}_{4}^{2-} / \mathrm{NH}_{4}^{+}$ ratio can therefore be used as marker for sulfate excess. A previous study from (Iizuka et al., 2002) presents the ratio of $\mathrm{Mg}^{2+} / \mathrm{Na}^{+}$as indicator of seasonal melting in an ice core from Svalbard. This method was applied for Chimborazo record and illustrated in Fig. 3. The results are different and rather help to define the core sections where $\mathrm{Mg}^{2+}$ (or $\mathrm{Ca}^{2+}$ ) re-depositions take place with ratios of $\sim 2 . \mathrm{Ca}^{2+}$ and $\mathrm{Mg}^{2+}$ react together under the elution process and their ratio confirms this identical position in the elution sequence. Both $\mathrm{Mg}^{2+} / \mathrm{Ca}^{2+}$ profiles did not report marked changes all over the cores confirming their identical behavior in normal, elution or re-deposition phases. The last discussed ratio is $\mathrm{Cl}^{-} / \mathrm{Na}^{+}$. If $\mathrm{Na}^{+}$and $\mathrm{Cl}^{-}$are incorporated together in the snow flakes as condensation nuclei aerosol originating only from sea salt, their ratio is close to 1.16 (dashed line in Fig. 3) (Keene et al., 1986). However, the mean ration observed in core A between 1 and $9 \mathrm{~m}$ weq depth is 0.91 indicating an additional but constant $\mathrm{Na}^{+}$input, when the high ratio close to the surface is related to the $\mathrm{Cl}^{-}$excess coming from the volcanic $\mathrm{HCl}$ deposition. In core $\mathrm{B}$, the $\mathrm{Cl}^{-} / \mathrm{Na}^{+}$ratio features high fluctuation between 1 and 12 indicating that the $\mathrm{Cl}^{-}$volcanic excess was eluted and diffused all over the core without preferential layers like for other strong acids.

\section{Conclusions}

In 1999 and 2000, two shallow ice cores were recovered on the same place from the summit of Chimborazo. In the same period, the eruption of the proximate Tungurahua volcano

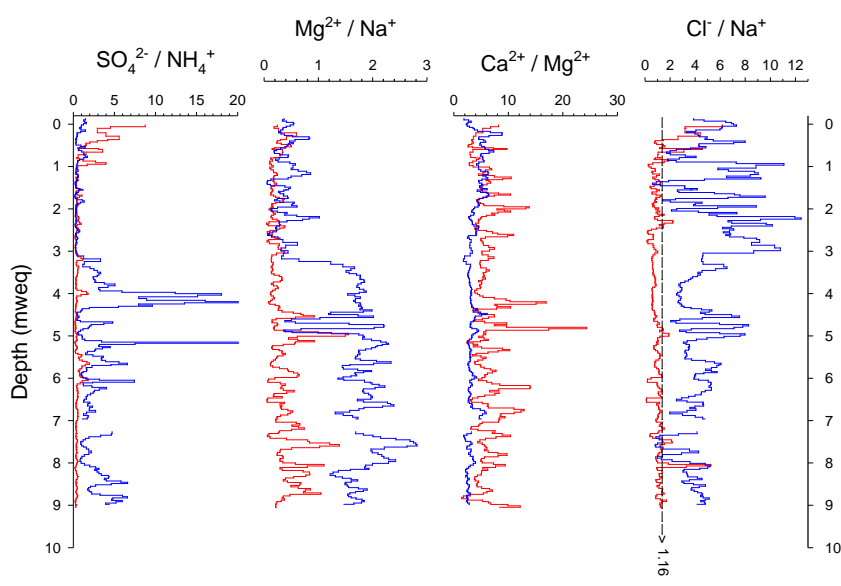

Fig. 3. the selected ionic ratios profiles for both Chimborazo ice cores (red line for core A, blue line for core B) illustrate the preferential elution and re-localization of some ionic species. For $\mathrm{Cl}^{-} / \mathrm{Na}^{+}$, the dashed line at 1.16 represent the sea salt ratio from (Keene et al., 1986).

reached the height of his power and covered the neighborhood and the Chimborazo glacier with ash and acid deposits. The comparison of both ice cores permits an evaluation of the impact of these perturbations on the ice core chemistry and an investigation of the processes of isotopic and ionic elution and re-localization. Only the upper meter of the record shows some changes in the stable isotope records indicating that water melted from the surface refreeze and is stored in that upper section. Below, until $9 \mathrm{~m}$ weq depth, melt water only percolates through firn layers, without refreezing. Some ions exhibits strong elution and re-localization like others seems to be less mobile under the effect of surface water percolation, leading to elution sequence: $\mathrm{SO}_{4}^{2-}>\mathrm{Ca}^{2+}>\mathrm{Mg}^{2+}>$ $\mathrm{F}^{-}>\mathrm{Na}^{+}=\mathrm{K}^{+}>\mathrm{Cl}^{-}>\mathrm{NO}_{3}^{-}>\mathrm{HCOO}^{-}=\mathrm{NH}_{4}^{+}$. The comparison between both cores reveals also the major volcanic eruption input of $\mathrm{Ca}^{2+}, \mathrm{Mg}^{2+}, \mathrm{F}^{-}, \mathrm{Cl}^{-}$, and $\mathrm{SO}_{4}^{2}$, first deposited on the glacier surface snow in 1999 and eluted and re-deposited deeper in 2000. Species integrated in the snowpack by exceptional event like volcanic eruption or stocked on the surface snow flakes by atmospheric scavenging are preferentially flushed out and re-deposited in deeper preferential layers. Nevertheless, for $\mathrm{Na}^{+}, \mathrm{K}^{+}$and $\mathrm{HCOO}^{-}$, the comparison shows that one fraction of these species is lost with the loaded percoling water or re-deposited deeper. The complete analyzes of the other $54 \mathrm{~m}$ parallel ice core also recovered in 2000 and reaching bedrock should bring complementary information.

Concerning the potential of Chimborazo ice cores to reconstruct past environmental and climatic conditions, it depends to the frequencies of such volcanic perturbation. As we know, Tungurahua is one of Ecuador's most active volcanoes. Prior to a long-term eruption beginning in 1995 that caused the temporary evacuation of the city of Baños at the 
foot of the volcano, the last major eruption had occurred from 1916 to 1918 , although minor activity continued until 1925. The time span covered by the $54 \mathrm{~m}$ long ice core should cover the 20th century, so that some portions of the record may conserve their original composition. Otherwise, the available unperturbed proxies are reduced to stable isotopes and some ionic species $\left(\mathrm{NH}_{4}^{+}, \mathrm{NO}_{3}^{-}, \mathrm{HCOO}^{-}\right)$. On the other hand, the stratigraphical examination of the $54 \mathrm{~m}$ core reveals a large number of ash layers mostly observed in the deepest $20 \mathrm{~m}$ ( 70 layers, H. Bonnaveira, personal communication, 2001) that could indicate that the time range covered by this core may be longer.

Acknowledgements. Lead author was member of PSI and University of Bern until 2001. This study and both field operations were supported by IRD and LGGE (Grenoble, France), the PSI (Villigen, Switzerland) and their local partners INAHMI and EPN (Quito, Ecuador). One of the leaders of the expedition received an important private contribution from the Rolex Awards for Enterprise. We would like to thank Patrick Wagnon, Jean-Robert Petit, Bernard Pouyaud, Robert Gallaire, Jean-Denis Taupin, Etienne Berthier, Beat Rufibach, Felix Stampfli for their help during the drilling expedition. A. Rivera, V. Pohjola, A. Svensson and an anonymous referee are acknowledged for their comments and corrections.

\section{Edited by: A. Rivera}

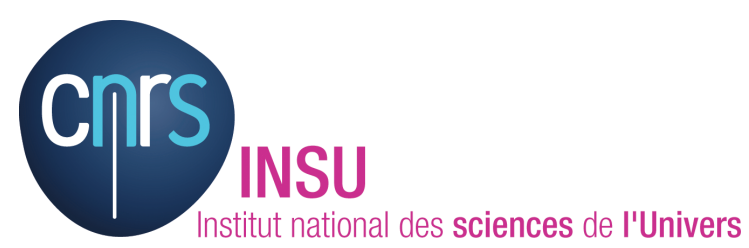

The publication of this article is financed by CNRS-INSU.

\section{References}

Brimblecombe, P., Tranter, M., Abrahams, P. W., Blackwood, I., Davies, T. D., and Vincent, C. E.: Relocation and preferential elution of acidic solute through the snowpack of a small, remote, high-altitude scottish catchment, Ann. Glaciol., 7, 141147, 1985.

Davies, T. D., Vincent, C. E., and Brimblecombe, P.: Preferential elution of strong acids from a Norwegian ice cap, Nature, 300, 161-163, 1982.

Delmas, R. J.: Environmental information from ice cores, Rev. Geophys., 30, 1-21, 1992.

Döscher, A., Gäggeler, H. W., Schotterer, U., and Schwikowski, M.: A 130 years deposition record of sulfate, nitrate and chloride from a high-alpine glacier, Water Air Soil Poll., 85, 603-609, 1995.

Eichler, A., Schwikowski, M., Gäggeler, H. W., Furrer, V., Synal, H. A., Beer, J., Saurer, M., and Funk, M.: Glaciochemical dating of an ice core from upper Grenzgletscher (4200 m a.s.1.), J. Glaciol., 46, 507-515, 2000.
Eichler, A., Schwikowski, M., and Gäggeler, H. W.: Meltwater induced relocation of chemical species in Alpine firn, Tellus B, 53B, 192-203, 2001.

Garcia, M., Villalba, F., Araguas-Araguas, L., and Rozanski, K.: The role of atmospheric circulation patterns in controlling the regional distribution of stable isotope contents in precipitation: preliminary results from two transects in the Ecuadorian Andes, Isotope Techniques in the Study of Environmental Change, Vienna, 127-140, 1998.

Ginot, P., Kull, C., Schwikowski, M., Schotterer, U., and Gäggeler, H. W.: Effects of post-depositional processes on snow composition of a subtropical glacier (Cerro Tapado, Chilean Andes), J. Geophys. Res., 106, 32375-32386, 2001.

Ginot, P., Schwikowski, M., Schotterer, U., Gäggeler, H. W., Gallaire, R., and Pouyaud, B.: Potential for climate variability reconstruction from Andean glaciochemical records, Ann. Glaciol., 35, 443-450, 2002.

Grumet, N. S., Wake, C. P., Zielinski, G. A., Fisher, D. A., Koerner, R. M., and Jacobs, J., D.: Preservation of glaciochemical timeseries in snow and ice from the Penny Ice Cap, Baffin Island, Geophys. Res. Lett., 25, 357-360, 1998.

Henderson, K. A., Thompson, L. G., and Lin, P. N.: Recording of El Niño in an ice core $\delta^{18} \mathrm{O}$ records from Nevado Huascaran, Peru, J. Geophys. Res., 104, 31053-31065, 1999.

Herron, M. M. and Langway, C. C.: Firn densification: an empirical model, J. Glaciol., 25, 373-385, 1980.

Hou, S. and Qin, D.: The effect of postdepositional process on the chemical profiles of snow pits in the percolation zone, Cold Reg. Sci. Technol., 34, 111-116, 2002.

Iizuka, Y., Igarashi, M., Kamiyama, K., Motoyama, H., and Watanabe, O.: Ratios of $\mathrm{Mg}^{2+} / \mathrm{Na}^{+}$in snowpack and an ice core at Austfonna ice cap, Svalbard, as an indicator of seasonal melting, J. Glaciol., 48, 452-460, 2002.

Kang, S., Mayewski, P. A., Qin, D., Yan, Y., Hou, S., Zhang, D., Ren, J., and Kreutz, K.: Glaciochemical records from a Mt. Everest ice core: relationship to atmospheric circulation over Asia, Atmos. Environ., 36, 3351-3361, 2002.

Keene, W. C., Pszenny, A. A. P., Galloway, J. N., and Hawley, M. E.: Sea-salt corrections and interpretation of constituent ratios in marine precipitation., J. Geophys. Res., 91, 6647-6658, 1986.

Knüsel, S., Ginot, P., Schotterer, U., Schwikowski, M., Gaeggeler, H. W., Francou, B., Simões, J. C., Petit, J. R., and Taupin, J. D.: Dating of two nearby ice cores from the Illimani, Bolivia, J. Geophys. Res., 108(D6), 4181-4191, 2003.

Kreutz, K. J. and Sholkovitz, E. R.: Major element, rare earth element, and sulfur isotopic composition of a high-elevation firn core: Sources and transport of mineral dust in central Asia, Geochem. Geophy. Geosy., 1, 1048-1071, 2000.

Legrand, M. and De Angelis, M.: Light carboxylic acids in Greenland ice: a record of past forest fires and vegetation emissions from the boreal zone, J. Geophys. Res., 101, 4129-4145, 1996.

Legrand, M. and Mayewski, P. A.: Glaciochemistry of polar ice cores: A review, Rev. Geophys., 35, 219-243, 1997.

Legrand, M., de Angelis, M., Staffelbach, T., Neftel, A., and Stauffer, B.: Large perturbations of ammonium and organic acid content in the summit Greenland ice core. Fingerprint from forest fires?, Geophys. Res. Lett., 19, 473-475, 1992.

Olivier, S., Schwikowski, M., Brütsch, S., Eyrikh, S., Gäggeler, H. W., Lüthi, M., Papina, T., Saurer, M., Schotterer, U., Tobler, L., 
and Vogel, E.: Glaciochemical investigation of an ice core from Belukha glacier, Siberian Altai, Geophys. Res. Lett., 30, 2019, doi:2010.1029/2003GL018290, 2003.

Pohjola, V. A., Moore, J. C., Isaksson, E., Jauhiainen, T., van de Wal, R. S. W., Martma, T., Meijer, H. A. J., and Vaikmäe, R.: Effect of periodic melting on geochemical and isotopic signals in an ice core from Lomonosovfonna, Svalbard, J. Geophys. Res., 107(D4), 4036-4050, 2002.

Preunkert, S., Wagenbach, D., Legrand, M., and Vincent, C.: Col du Dôme (Mt Blanc Massif, French Alps) suitability for ice-core studies in relation with past atmospheric chemistry over Europe, Tellus, 52B, 993-1012, 2000.

Schotterer, U., Fröhlich, K., Gäggeler, H. W., Sandjordj, S., and Stichler, W.: Isotope records from Mongolian and Alpine ice cores as climate indicators, Climate Change, 36, 519-530, 1997.

Schotterer, U., Grosjean, M., Stichler, W., Ginot, P., Kull, C., Bonnaveira, H., Francou, B., Gäggeler, H. W., Gallaire, R., Hoffmann, G., Pouyaud, B., Ramirez, E., Schwikowski, M., and Taupin, J. D.: Glaciers and climate in the Andes between the Equator and $30^{\circ} \mathrm{S}$ : What is recorded under extreme environmental conditions?, Climatic Change, 59, 157-175, 2003.

Schotterer, U., Stichler, W., and Ginot, P.: The influence of postdepositional effects on ice core studies: examples from the Alps, Andes, and Altaï, in: Earth Paleoenvironments: Records preserved in Mid- and Low-Latitude Glaciers, edited by: De Wayne Ceciel, L., Green, J. R., and Thompson, L. G., Developments in Paleoenvironmental Research Series, Kluwer Academic Publishers, 39-60, 2004.

Schwikowski, M., Brütsch, S., Gäggeler, H. W., and Schotterer, U.: A high-resolution air chemistry record from an Alpine ice core: Fiescherhorn glacier, Swiss Alps, J. Geophys. Res., 104, 1370913719, 1999.

Stichler, W., Schotterer, U., Fröhlich, K., Ginot, P., Kull, C., Gäggeler, H. W., and Pouyaud, B.: The influence of sublimation on stable isotopes records from high altitude glaciers in the tropical Andes, J. Geophys. Res., 106, 22613-22621, 2001.
Thompson, L. G., Hastenrath, S., and Morales Arnao, B.: Climatic ice core records from the tropical Quelccaya ice cap, Science, 203, 1240-1243, 1979.

Thompson, L. G., Mosley-Thompson, E., Davis, M. E., Lin, P.-N., Henderson, K. A., Cole-Dai, J., Bolsan, J. F., and Lui, K.-B.: Late glacial stage and Holocene tropical ice core records from Huascaran, Peru, Science, 269, 46-50, 1995.

Thompson, L. G., Yao, T., Davis, M. E., Henderson, K. A., MosleyThompson, E., Lin, P.-N., Beer, J., Synal, H.-A., Cole-Dai, J., and Bolzan, J. F.: Tropical Climate Instability: The Last Glacial Cycle from a Qinghai-Tibetan Ice Core, Science, 276, 1821$1825,1997$.

Thompson, L. G., Davis, M. E., Mosley-Thompson, E., Sowers, T. A., Henderson, K. A., Zagorodnov, V. S., Lin, P.-N., Mikhalenko, V. N., Campen, R. K., Bolzan, J. F., Cole-Dai, J., and Francou, B.: A 25000-year tropical climate history from Bolivian ice cores, Science, 282, 1858-1864, 1998.

Thompson, L. G., Yao, T., Mosley-Thompson, E., Davis, M. E., Henderson, K. A., and Lin, P. N.: A high-resolution millenial record of the South Asian monsoon from Himalayan ice cores, Science, 289, 1916-1919, 2000.

Thompson, L. G., Mosley-Thompson, E., Davis, M. E., Henderson, K. A., Brecher, H. H., Zagorodnov, V. S., Mashiotta, T. A., Lin, P.-N., Mikhalenko, V. N., Hardy, D. R., and Beer, J.: Kilimanjaro Ice Core Records: Evidence of Holocene Climate Change in Tropical Africa, Science, 298, 589-593, 2002.

Tsiouris, S., Vincent, C. E., Davies, T. D., and Brimblecombe, P.: The elution of ions through field and laboratory snowpacks, Ann. Glaciol., 7, 196-2001, 1985.

Vuille, M., Bradley, R. S., and Keimig, F.: Climate variability in the Andes of Ecuador and its relation to tropical Pacific and Atlantic sea surface temperature anomalies, J. Climate, 13, 2520-2535, 2000 . 